\title{
Peculiarities of water-electrolytic metabolism of rats with "slow" type of acetylation after a combined effect of cadmium chloride and sodium nitrate
}

\author{
N.D. Filipets, T.I. Kmet, T.I. Hrachova \\ Higher State Educational Establishment of Ukraine «Bukovinian State Medical University», Chernivtsi; \\ e-mail: filipec.natalja@bsmu.edu.ua
}

\begin{abstract}
After a combined 14 days introduction of cadmium chloride $(0,1 \mathrm{mg} / \mathrm{kg}$ intraperitoneally) and sodium nitrate (500 mg/kg intragastrically) to mature nonlinear albino rats with "slow" type of acetylation changes of water-electrolytic metabolism were manifested by $6,3 \%$ increased concentration of sodium ions in the blood plasma. Hypernatremia resulted from the disorders of water, ion, and osmoregulatory renal functions induced by both nephrotoxic substances. Stability of potassium metabolism indices was indicative of the retention of a functional state in the distal portion of the nephron. The combination with sodium nitrate restrained a harmful effect of cadmium chloride on the glomerular sector of a nephron and glomerular filtration rate (GFR) did not change. Taking into account the lack of activation of glomerular processes in response to penetration of exotoxins into the body GFR can be considered as a predictor of nephropathy progression in rats with "slow" type of acetylation. 6,9\% increase of proximal reabsorption of sodium ions under conditions of stable GFR was indicative of disorders of the glomerular-tubular balance due to dysfunction of the nephron proximal portion. At the same time, it is reasonable to present the evidence of our opinion by the analysis of interrelations between the indices of functional-biochemical kidney conditions considering biochemical criteria of acetylation type in mature rats with "slow" acetylation type under conditions of a combined effect of cadmium chloride and sodium nitrate, which are the prospects of further investigations. Key words: water-electrolytic metabolism; mature rats; «slow» acetylation type; cadmium chloride; sodium nitrate.
\end{abstract}

\section{INTRODUCTION}

Generally recognized interrelation between certain body organs and systems assumes availability of integrated functional changes ensuring certain adaptive reactions in response to unfavourable conditions. At the same time, results of functional responses depend on metabolic processes which parameters should correspond to the requirements of the regulation systems under physiological and pathological conditions. The total sum of these mutually specified mechanisms forms functional-metabolic continuum (FMC) [1]. The main FMC principles are coherence in the work of regulatory and executive systems including cells, heart-kidneys, liver-kidneys. Due to clinical pathophysiological analysis common mechanisms of interaction between different organs and systems are de(C) N.D. Filipets, T.I. Kmet, T.I. Hrachova termined under conditions of their damage. On the other hand, in addition to general regularities there are considerable individual peculiarities of pathogenesis caused by genotype and phenotype features. Biological activity of acetylation processes is genetically determined ability of the body. It is a prevailing way to biological transformation of xenobiotics and endogenous compounds. The mechanisms of acetylation are still examined today. Individuals with "rapid" and "slow" acetylation types are known to differ by pharmacokinetics of drugs and efficacy of pharmacotherapy as well as development of certain diseases [2-6]. The most intensive acetylation occurs in the liver, and acetylated metabolites are mostly eliminated by the renal processes. Susceptibility to nephropathy and functional renal ability, directed to an adequate 
water-salt supply of cells, are likely to depend on acetylation phenotype [7]. Returning to the previous substantiation of FMC it should be noted that water-electrolytic balance is an essential term for integrated vital ability of the organism.

Detection of early mechanisms of the hepatic-renal syndrome at the initial stage of acute toxic nephropathy [8] logically motivates examination of water-electrolytic metabolism in case of kidney damage depending on the acetylation type. At the same time, detection of the role of acetylation system in adaptive response of the body under unfavourable environmental conditions, effect of heavy metal salts and nitrogen compounds in particular, is of an important practical value. Thus, our previous investigations on rats with different acetylation type have determined age differences of susceptibility biochemical markers to the influence of nephrotoxic substances cadmium chloride and sodium nitrate [9].

Objective of our work at this stage is to examine changes in the renal functions characterizing the state of water-electrolytic metabolism in mature rats with slow acetylation type after a combined effect of cadmium chloride and sodium nitrate.

\section{METHODS}

The study was performed on laboratory nonlinear albino male rats 6 months of age with the body weight of 0.16-0.18 kg kept under standard vivarium conditions on well-balanced forage. The rate of acetylation was estimated according to the methods [10]. Rats with a "slow" type of acetylation were divided into 2 groups: I - control (intact) group, II - group with simulated subacute cadmium-nitrate intoxication. To simulate the model rats were injected with cadmium chloride during 14 days intraperitoneally in the dose of $0.1 \mathrm{mg} / \mathrm{kg}\left(1 / 150 \mathrm{DL}_{50}\right)$ and sodium nitrate intragastrically (through the probe) in the dose of $500 \mathrm{mg} / \mathrm{kg}\left(1 / 15 \mathrm{DL}_{50}\right)$. During the whole period of the experiment the control group was injected with isotonic solution of sodium chloride (intraperitoneally) and settled tap water (intragastrically) instead of external poisonous substances. 24 hours after the last introduction all the rats were subjected to $5 \%$ water load (tap water, intragastrically) and placed into exchange cages to collect urine. Diuresis was registered every 2 hours, blood was taken in the amount of $20 \mathrm{mg} / \mathrm{kg}$ from rats narcotized by means of $1 \%$ of sodium ethaminal solution. The concentration of sodium and potassium ions in urine and blood plasma was determined by means of flame photometry method on «ФПЛ-1». То assess glomerular filtration rate creatinine in the urine was determined by Folin's method, in the blood plasma - by Popper's method in Paul Merson's modification [11]. The findings were statistically processed by means of statistical analysis applying parametric statistical methods according to the programs «Statgrafics», «Excel 7.0». The parameters standardized by the body mass and the volume of glomerular filtration (GF) were calculated by means of formulas [12]. Estimation differences between samples were assessed by means of Student t-criterion.

\section{RESULTS AND DISCUSSION}

The data presented in the Table indicate that introduction of cadmium chloride and sodium nitrate during 14 days in mature rats with "slow" acetylation type causes $6.3 \%$ increase of natremia level. Increased concentration of sodium ions in the blood plasma according to the notion concerning the regulation of salts and fluids in the body is stipulated by water imbalance. We have not found statistically valuable changes of volume regulating renal function: indices of diuresis, water reabsorption and water excretion free of sodium ions did not differ from that of the control. Even small doses of cadmium chloride are known to be neurotoxic for mammals and humans and modify vasopressinergic neuron system in the absence of direct changes of water metabolism [13]. At the same time, sodium ions are determinants of plasma osmolality regulating movement of water between extra- and intracellular sectors of the body. Most often hypernatre- 
mia is indicative of regulation control disorders from the side of antidiuretic hormone (reduced concentration) or decreased reactions of the kidneys damaged by nephrotoxic substances, which prevents normalization of water content in the blood plasma and restoration of sodium ions concentration. Dyshidria with accumulation of water in the interstitial and intracellular space is likely to be formed in mature rats with "slow" acetylation type under the effect of cadmium chloride and sodium nitrate.

It should be noted that in other experimental studies of osmoregulation mechanisms under conditions of cadmium-containing diet without consideration of acetylation type plasma osmolality did not change, although urine osmolality increased and diuresis decreased [14]. We observed $24.2 \%$ increase of sodium ions concentration in the urine, and 1.2 times increase - blood/urine ratio concentrations without clearance changes of this electrolyte. Contrary to the conclusions suggested by the authors [14], increased urine concentration should not be considered as the reaction to maintain waterelectrolytic state. Under conditions of cadmium effect kidneys are the most susceptible organ. Cadmium ions are accumulated in the proximal tubule cells including lysosomes [15]. In spite of adaptive activation of autophagia detected in the cortical layer of the kidneys to ensure breaking down of damaged proteins, long-term cadmium intoxication is considered to deteriorate autophagia efficacy [15]. In the same way accumulation of protein degradation products damages renal cells, changes tubular functions determining sodium ions retention in the body. Relative and standardized reabsorption of sodium ions increased (6.9\%) against the ground of hypernatremia. Increase of sodium ions results in increased water outcome from the renal tubules and formation of interstitial swelling, which is the evidence of suggestion concerning redistribution of water into the side of the intracellular space in our study. Such a sequence of renal reactions is likely to prevent excessive excretion of sodium ions from the organism: increased indices of sodium ions excretion were not statistically significant.

It should be noted that changes of potassium metabolism indices were not found. According to modern notions both the processes of secretion and reabsorption of potassium ions can occur in one and the same cell of the distal renal tubules. Stability of kalemia, concentration of potassium ions in the urine and their excretion were indicative of a normal functioning of the distal nephron portion. Therefore, sodium imbalance occurred due to functional changes of the convoluted tubules of the proximal portion.

A general link of pathogenic mechanisms stipulating toxic nephropathy is a primary dysfunction of the proximal tubules. Although disorders of proximal reabsorption of sodium ions are the most important among important signs of direct damage of the tubular sector [16-18]. In our study increase of this index can result from reduced activity of atrial natriuretic peptide (ANP) due to toxic effect of cadmium chloride on the functional-biochemical condition of the myocardium [19].

Nephropathy induced by cadmium is characterized by reduced filtration ability of the kidneys, although the levels of creatininemia and GFR in our study did not change. According to the results of other studies cadmium chloride influence in mature rats caused decreased GFR and it was functional response to inhibition of proximal reabsorption. At the same time, electron-microscopic examinations found considerable degenerative changes in the proximal tubular epithelial cells and diffuse thickening of the glomerular basal membranes [20]. As it has been mentioned, proximal transport of sodium ions increased under conditions of a combined effect of cadmium chloride and sodium nitrate. Damaging effects of cadmium chloride on the vascular-glomerular and tubular levels most likely prevented sodium nitrate effect. Nitrates and nitrites in vivo with inconsiderable or without systemic transformation into NO are known to influence on the renal tubules and vascular bed [21]. Vasodilation maintains renal blood cir- 
culation and GFR. From other positions kidneys are responsible for the excretion of endogenous and exogenous nitrates and other toxic substances of any origin. Absence of functional changes and increase of GFR in particular, prevents proportional secretion increase of both nephrotoxic substances. Decreased rates of renal excretion make negative effects of cadmium chloride and sodium nitrate longer, and naturally progressing decrease of the number of functioning nephrons in rats with "slow" acetylation type.

Therefore, a combined introduction of cadmium chloride and sodium nitrate during 14 days to mature rats with "slow" acetylation type results in changes of water-electrolytic metabolism manifested by increased concentration of sodium ions in the blood plasma. Hypernatre- mia resulted from the disorders of water, ion, and osmoregulatory renal functions induced by both nephrotoxic substances. Stability of potassium metabolism indices was indicative of the retention of a functional state in the distal portion of the nephron. The combination with sodium nitrate restrained a harmful effect of cadmium chloride on the glomerular sector of a nephron and glomerular filtration rate (GFR) did not change. Taking into account the lack of activation of glomerular processes in response to penetration of exotoxins into the body GFR can be considered as a predictor of nephropathy progression in rats with "slow" type of acetylation. Increase of proximal reabsorption of sodium ions under conditions of stable GFR was indicative of disorders of the glomerular-tubular

Indices of water-electrolytic metabolism of mature rats with "slow" acetylation type after 14 days introduction of cadmium chloride $(0.1 \mathrm{mg} / \mathrm{kg}$ intraperitoneally) an sodium nitrate $(500 \mathrm{mg} / \mathrm{kg}$ intragastrically $),(M \pm \mathrm{m}, \mathrm{n}=7)$

\begin{tabular}{|c|c|c|}
\hline \multirow[b]{2}{*}{ Indices } & \multicolumn{2}{|c|}{ "Slow" acetylizers } \\
\hline & Control & $\begin{array}{l}\text { Cadmium chloride } \\
\text { and sodium nitrate }\end{array}$ \\
\hline Diuresis, $\mathrm{ml} / 2 \mathrm{~h}$ & $3.5 \pm 0.20$ & $3.4 \pm 0.37$ \\
\hline Relative diuresis, $\%$ & $70.3 \pm 4.15$ & $68.8 \pm 7.58$ \\
\hline Glomerular filtration rate, $\mu 1 / \mathrm{min}$ & $404.7 \pm 21.30$ & $423.2 \pm 28.50$ \\
\hline Relative reabsorption of $\mathrm{H}_{2} \mathrm{O}, \%$ & $92.7 \pm 0.12$ & $93.2 \pm 0.66$ \\
\hline Plasma $\mathrm{Na}^{+}, \mathrm{mmol} / 1$ & $134.2 \pm 1.18$ & $142.8 \pm 1.38(\mathrm{P}<0.01)$ \\
\hline Urine $\mathrm{Na}^{+}, \mathrm{mmol} / \mathrm{l}$ & $1.94 \pm 0.132$ & $2.41 \pm 0.089(\mathrm{P}<0.05)$ \\
\hline Excretion of $\mathrm{Na}^{+}, \mu \mathrm{mol} / 2 \mathrm{~h}$ & $6.87 \pm 0.689$ & $8.22 \pm 0.86$ \\
\hline Relative reabsorption of $\mathrm{Na}^{+}, \%$ & $99.89 \pm 0.008$ & $99.87 \pm 0.003(\mathrm{P}<0.05)$ \\
\hline Clearance of $\mathrm{H}_{2} \mathrm{O} \mathrm{Na}^{+}, \mathrm{ml} / 2 \mathrm{~h}$ & $3.46 \pm 0.204$ & $3.38 \pm 0.374$ \\
\hline Urine $\mathrm{Na}^{+} /$Plasma $\mathrm{Na}^{+}$, units & $0.014 \pm 0.001$ & $0.018 \pm 0.001(\mathrm{P}<0.05)$ \\
\hline Clearance of $\mathrm{Na}^{+}, \mathrm{ml} / 2 \mathrm{~h}$ & $0.05 \pm 0.005$ & $0.06 \pm 0.006$ \\
\hline Proximal reabsorption of $\mathrm{Na}^{+}, \mathrm{mmol} / 2 \mathrm{~h}$ & $464.7 \pm 26.27$ & $483.7 \pm 54.76$ \\
\hline Distal reabsorption of $\mathrm{Na}^{+}, \mu \mathrm{mol} / 2 \mathrm{~h}$ & $6.04 \pm 0.29$ & $6.7 \pm 0.46$ \\
\hline Excretion of $\mathrm{Na}^{+}, \mu \mathrm{mol} / 100 \mu \mathrm{GF}$ & $1.68 \pm 0.130$ & $1.92 \pm 0.137$ \\
\hline Proximal reabsorption of $\mathrm{Na}^{+}, \mathrm{mmol} / 100 \mu \mathrm{lGF}$ & $12.4 \pm 0.11$ & $13.3 \pm 0.15(\mathrm{P}<0.01)$ \\
\hline Distal reabsorption of $\mathrm{Na}^{+}, \mu \mathrm{mol} / 100 \mu \mathrm{GF}$ & $0.96 \pm 0.018$ & $0.95 \pm 0.097$ \\
\hline
\end{tabular}

Notes: $\mathrm{P}$ - reliability in comparison with the control rats; $\mathrm{n}$ - number of rats in every group; GF - glomerular filtrate. 
balance due to dysfunction of the nephron proximal portion. At the same time, it is reasonable to present the evidence of our opinion by the analysis of interrelations between the indices of functional-biochemical kidney conditions considering biochemical criteria of acetylation type in mature rats with "slow" acetylation type under conditions of a combined effect of cadmium chloride and sodium nitrate, which are the prospects of further investigations.

The authors of this study confirm that the research and publication of the results were not associated with any conflicts regarding commercial or financial relations, relations with organizations and/or individuals who may have been related to the study, and interrelations of coauthors of the article.

\section{Н.Д. Філіпець, Т.І. Кметь, Т.І. Грачова}

ОСОБЛИВОСТІ ВОДНО-ЕЛЕКТРОЛІТНОГО ОБМІНУ ЩУРІВ ІЗ «ПОВІЛЬНИМ» ТИПОМ АЦЕТИЛЮВАННЯ ПІСЛЯ ПОСДНАНОГО ВПЛИВУ ХЛОРИДУ КАДМІЮ ТА НІТРАТУ НАТРІЮ

Після поєднаного введення впродовж 14 діб хлориду кадмію $(0,1$ мг/кг внутрішньоочеревинно) і нітрату натрію (500 мг/кг внутрішньошлунково) статевозрілим нелінійним білим щурам із «повільним» типом ацетилювання зміни водно-електролітного обміну проявлялися підвищенням на 6,3 \% концентрації іонів натрію в плазмі крові. Гіпернатріємія була наслідком індукованих обома нефротоксикантами порушень водо-, іоно-, осморегулювальної функцій нирок. Стабільність показників калієвого обміну вказувала на збереження функціонального стану дистального відділу нефрону. Поєднання з нітритом натрію стримувало пошкоджуючий вплив кадмію хлориду на клубочковий сектор нефрону і швидкість клубочкової фільтрації (ШКФ) не змінювалася. Беручи до уваги відсутність активації клубочкових процесів у відповідь на надходження в організм екзотоксикантів, можна вважати ШКФ предиктором прогресування нефропатії у щурів «повільних ацетиляторів». Підвищення проксимальної реабсорбції іонів натрію на 6,9 \% за умов стабільної ШКФ вказувало на порушення клубочково-канальцевого балансу внаслідок дисфункції проксимального відділу нефрону. Водночас для підтвердження наших суджень доцільним $€$ аналіз взаємозв'язку показників функціонально-біохімічного стану нирок із урахуванням біохімічних критеріїв типу ацетилювання у статевозрілих щурів «повільних» ацетиляторів за умов поєднаного впливу хлориду кад- мію та нітрату натрію, що є перспективою подальших досліджень.

Ключові слова: водно-електролітний обмін; статевозрілі щури; «повільний» тип ацетилювання; хлорид кадмію; нітрат натрію.

Вищий державний навчальний заклад Украйни «Буковинський державний медичний університет», Чернівиі

\section{Н.Д. Филипец, Т.И. Кметь, Т.И. Грачева}

\section{ОСОБЕННОСТИ ВОДНО-ЭЛЕКТРОЛИТ- НОГО ОБМЕНА ПОЛОВОЗРЕЛЫХ КРЫС С «МЕДЛЕННЫМ» ТИПОМ АЦЕТИЛИРО- ВАНИЯ ПОСЛЕ СОЧЕТАННОГО ВЛИЯНИЯ ХЛОРИДА КАДМИЯ И НИТРАТА НАТРИЯ}

После комбинированного введения в течение 14 сут хлорида кадмия $(0,1$ мг/кг внутрибрюшинно) и нитрата натрия (500 мг/кг внутрижелудочно) половозрелым нелинейным белым крысам с «медленным» типом ацетилирования изменения водно-электролитного обмена проявлялись повышением на 6,3 \% концентрации ионов натрия в плазме крови. Гипернатриемия была следствием индуцированных обоими нефротоксикантами нарушений водо-, ионо-, осморегулирующей функций почек. Стабильность показателей калиевого обмена указывала на сохранение нормального функционального состояния дистального отдела нефрона. Сочетание с нитритом натрия сдерживало повреждающее влияние кадмия хлорида на клубочковый сектор нефрона и скорость клубочковой фильтрации (СКФ) не изменялась. Принимая во внимание отсутствие активации клубочковых процессов в ответ на поступления в организм экзотоксикантов, можно считать СКФ предиктором прогрессирования нефропатии у крыс с «медленным» типом ацетилирования. Повышение проксимальной реабсорбции ионов натрия на $6,9 \%$ при стабильной СКФ указывало на нарушение клубочково-канальцевого баланса вследствие дисфункции проксимального отдела нефрона. Однако для подтверждения наших суждений целесообразным является анализ взаимосвязей показателей функциональнобиохимического состояния почек с учетом биохимических критериев типа ацетилирования у половозрелых крыс с «медленным» типом ацетилирования в условиях комбинированного воздействия хлорида кадмия и нитрата натрия, что является перспективой дальнейших исследований.

Ключевые слова: водно-электролитный обмен; половозрелые крысы; «медленный» тип ацетилирования; хлорид кадмия; нитрат натрия.

\section{REFERENCES}

1. Gozhenko AI. Theory of the disease: monograph. Odessa: Fenix, 2018. [Ukrainian]. 
2. Spinasse LB, Santos AR, Suffys PN, Muxfeldt ES, Salles GF. Different phenotypes of the NAT2 gene influences hydralazine antihypertensive response in patients with resistant hypertension. Pharmacogenomics. 2014;15(2):169-8.

3. Korotun OP, Vlasyk LI. Hygienic evaluation of the oral influence of imidacloprid in immature animals with different acetylation activity. Environment\&health. 2014;2:7-11. [Ukrainian].

4. Petrynych VV., Vlasyk LI. The influence of acetylation on the behavioral responses of rats in conditions of lead intoxication. Environment\&health. 2014;4:10-3. [Ukrainian].

5. Marusyk UI. Immune and atopic status of school-age children with asthma, given the asthma phenotype. Lik Sprava. 2014;7-8:10-4. [Ukrainian].

6. Doll MA, Hein DW. Genetic heterogeneity among slow acetylator $\mathrm{N}$-acetyltransferase 2 phenotypes in cryopreserved human hepatocytes. Arch Toxicol. 2017; 91(7): 2655-61.

7. Soblirova ZnKh, Kharina EA. Is Rapid Acetylation a Predictor of Kidney and Urinary Tract Diseases. Nephrology and dialysis. 1991;1(1):20-3. [Russian].

8. Rohovyy YuYe, Zlotar OV, Filipova LO. Pathophysiology of hepatorenal syndrome at the polyuric stage of sublimate nephropathy. Chernivtsi: Medical University, 2012. [Ukrainian].

9. Trachtenberg IM, Korshun MM, Prodanchuk MG, Kmet TI. Essays on age toxicology: monograph. Kyiv: Avicenna, 2005. [Ukrainian].

10. Pershin GN. Methods of experimental chemotherapy (practical guide) / ed. GN. Pershina: 2nd edition. Moscow: Medicine, 1971;453-7. [Russian].

11. Berchin EB, Ivanov YuI. Methods of experimental study of kidneys and water-salt metabolism. Barnaul: The Altai Book Publishing house, 1972. [Russian].

12. Schück O. Examination of kidney function. Pragua: Avicenum, 1981.

13. Mbarek S, Saidi T, Mansour HB, Stephane MP, Rostene W, Chaouacha-Chekir RB. Effect of cadmium on water metabolism regulation by Meriones shawi (Rodentia, Muridae). Environm Eng Sci. 2011;28(3):237-8.

14. Mbarek S, Saidi T, Gonzalez-Costas JM, Gonzalez-Romero E, Chaouacha-Chekir RB. Effects of dietary cadmium exposure on osmoregulation and urine concentration mechanisms of the semi-desert rodent Meriones shawi. J Environ Monit. 2012;14:2212-8.

15. Chargui A, Zekri S, Jacquillet G, Rubera I, Ilie M, Belaid A, Duranton C, Tauc M, Hofman P, Poujeol P, El May MV, Mograbi B. Cadmium-induced autophagy in rat kidney: an early biomarker of subtoxic exposure. Toxicol Sci. 2011;121(1):31-2.

16. Gozhenko AI, Lugovskoy SP, Samokhina NA. The study of morphofunctional features of the development of experimental metallonephropathy. J Educ Health and Sport. 2016;6(4):287-96.

17. Boychuk TN, Gordienko VV, Rohovoy YuYe. Chronorhythms of the kidneys: the age-old aspect under the conditions of metallotoksikoza: a monograph. Chernivtsi: Medical University. 2016. [Ukrainian].

18. Filipets ND, Sirman VM, Gozhenko AI. A comparative analysis of tubuluprotective effects of the representatives of different classes of ion channel modulators under the conditions of chronization of toxic nephropathy. Ukrainian biopharmaceutical journal. 2014;5:25-8. [Ukrainian].

19. Saleh RM, Awadin WF Biochemical and histopathological changes of subacute cadmium intoxication in male rats. 2017;24(32): 25475-81.

20. Uriu K, Kaizu K, Komine N, Ikeda M, Qie YL, Hashimoto $\mathrm{O}$, Matsuoka A, Eto S. Renal hemodynamics in rats with cadmium-induced nephropathy. Toxicol Appl Pharmacol. 1998;150(1):76-85.

21. Rosenbaek JB, Al Therwani S, Jensen JM, Mose FH, Wandall-Frostholm C, Pedersen EB, Bech JN. Effect of sodium nitrite on renal function and sodium and water excretion and brachial and central blood pressure in healthy subjects: a dose-response study. Am J Physiol Renal Physiol. 2017;313(2):378-387.

Received 06.03.2018 